\title{
HUBUNGAN ANTARA KONSEP DIRI AKADEMIK, EFIKASI DIRI AKADEMIK, HARGA DIRI DAN PROKRASTINASI AKADEMIK PADA SISWA SMP NEGERI DI KOTA MALANG
}

\author{
Rahmawati Husnul Khotimah, Carolina L. Radjah, Dany M. Handarini \\ Bimbingan dan Konseling-Fakultas Ilmu Pendidikan-Universitas Negeri Malang-Jl. Semarang No. 5 Malang \\ Email: rahmahkh237@gmail.com
}

\begin{abstract}
This study aims to determine the relationship between academic self-concept, academic self-efficacy, self-esteem and academic procrastination. To achieve these goals, used a correlational study design. The population used in the study are students of Junior High School in Malang, the sample totaled 393 students obtained through a multistage random sampling method of sampling. To measure academic self-concept, academic self-efficacy, self-esteem and academic procrastination, use a scale of academic self-concept, academic self-efficacy scale, the scale of self-esteem and academic procrastination scale that has been tested for validity and reliability. The results showed that each variable that academic self-concept, academic self-efficacy and self-esteem negatively related to academic procrastination and together these three variables affect the academic procrastination.
\end{abstract}

Keywords: academic self-concept; academic self-efficacy; self-esteem; academic procrastination

\begin{abstract}
Abstrak: Penelitian ini bertujuan untuk mengetahui hubungan antara konsep diri akademik, efikasi diri akademik, harga diri dan prokrastinasi akademik. Untuk mencapai tujuan tersebut, digunakan rancangan penelitian korelasional. Populasi yang digunakan dalam penelitian ialah siswa SMP Negeri di Kota Malang, sampel penelitian berjumlah 393 siswa yang diperoleh melalui metode pengambilan sampel multistage random sampling. Untuk mengukur konsep diri akademik, efikasi diri akademik, harga diri dan prokrastinasi akademik, digunakan skala konsep diri akademik, skala efikasi diri akademik, skala harga diri dan skala prokrastinasi akademik yang telah teruji validitas dan reliabilitasnya. Hasil penelitian menunjukkan bahwa masing-masing variabel yaitu konsep diri akademik, efikasi diri akademik dan harga diri memiliki hubungan negatif terhadap prokrastinasi akademik dan secara bersama-sama ketiga variabel tersebut berpengaruh terhadap prokrastinasi akademik.
\end{abstract}

Kata kunci: konsep diri akademik; efikasi diri akademik; harga diri; prokrastinasi akademik.

Belajar merupakan tugas utama seorang siswa, namun tidak semua siswa memiliki pengelolaan belajar yang baik. Pengelolaan belajar dapat memengaruhi prestasi atau hasil belajar siswa. Masalah pengelolaan belajar yang sering dialami oleh siswa sekolah ialah penundaan dalam mengerjakan tugas. Perilaku menundanunda tugas akademik disebut dengan prokrastinasi akademik. Prokrastinasi menurut Ferrari (Ghufron, 2003:17) dapat dipandang dari berbagai batasan tertentu, diantaranya ialah prokrastinasi hanya sebagai perilaku penundaan, prokrastinasi sebagai suatu kebiasaan atau pola perilaku dan prokrastinasi sebagai suatu trait kepribadian. 
Berdasarkan penelitian terdahulu (Alvira, 2013) ditemukan data bahwa siswa masih menggunakan "Sistem Kebut Semalam(SKS)" untuk belajar, mengerjakan tugas satu hari sebelum dikumpulkan, mengerjakan tugas di sekolah sebelum bel masuk dibunyikan, mengobrol saat mengerjakan tugas dan keterlambatan mengumpulkan tugas. Hasil analisis data prokrastinasi akademik siswa SMP Negeri Malang oleh peneliti sendiri menunjukkan $81.5 \%$ siswa mengalami prokrastinasi akademik dalam kategori sedang, dan $1 \%$ dari 395 siswa sampel mengalami prokrastinasi akademik dalam kategori tinggi. Prokrastinasi memang banyak dilakukan oleh individu, tanpa memandang usia, jenis kelamin, atau statusnya sebagai pelajar atau pekerja.

Secara umum faktor-faktor yang mempengaruhi perilaku menunda atau prokarastinasi akademik dapat dikategorikan menjadi dua, yaitu faktor eksternal dan faktor internal. Faktor eksternal yaitu faktor yang terdapat dari luar diri individu meliputi: gaya pengasuhan orang tua dan kondisi lingkungan. Sedangkan faktor internal yaitu faktor yang ada pada diri individu yang melakukan prokrastinasi, yaitu unsur struktur kepribadian. Menurut Bandura (dalam Alwisol, 2009:284) struktur kepribadian saling determinis menempatkan semua hal saling berinteraksi, pusatnya ialah sistem self yang mengacu ke struktur kognitif kemudian memberi pedoman mekanisme dan seperangkat fungsi-fungsi persepsi, evaluasi dan pengaturan tingkah laku. Sehingga jika fungsi-fungsi persepsi dan evaluasi baik, maka tingkah laku yang nampak, khususnya prokrastinasi akademik tidak akan terjadi.

Konsep diri akademik adalah gambaran individu terhadap kemampuan akademiknya, yang meliputi kemampuan dalam mengikuti kegiatan pembelajaran, kemampuan meraih prestasi di bidang akademik, serta aktivitas di sekolah atau di kelas yang berkaitan dengan persepsi, pikiran, perasaan dan penilaian seseorang terhadap kemampuan akademiknya (Atmasari, 2009). Efikasi diri akademik diartikan sebagai keyakinan individu terhadap kemampuannya, semakin individu yakin terhadap kemampuannya, maka semakin besar usaha yang dilakukannya dan makin aktif ia karena ia yakin kemampuannya tersebut dapat membantu dalam mengerjakan suatu tugas dan membantu menghadapi hambatan/rintangan untuk mencapai prestasi akademik yang tinggi. Sedangkan self-esteem ialah penilaian mengenai individu mengenai hal-hal yang berkaitan dengan dirinya, baik dari pengalaman yang dialaminya maupun pengalaman yang dipelajari dari orang lain berkaitan pencapaian prestasi akademik. Menurut Worchel, dkk (dalam Dayakisni, 2009) selfesteem merupakan komponen evaluatif dari konsep diri, yang terdiri dari evaluasi positif dan negatif tentang diri sendiri.

Hasil penelitian yang dilakukan oleh Lampert (2007) mengenai hubungan antara self-efficacy akademik, konsep diri akademik dan prestasi akademik menunjukkan bahwa self-efficacy akademik adalah prediktor yang signifikan yang dapat digunakan dalam memprediksi prestasi akademik dibandingkan dengan konsep diri akademik. Sementara prestasi akademik individu dipengaruhi juga oleh kebiasaan menunda atau tidak tugas-tugas akademik seperti yang telah disampaikan sebelumnya. Erma (2013) dalam penelitiannya menunjukkan bahwa memang terdapat hubungan negatif yang sangat signifikan antara harga diri dengan prokrastinasi akademik mahasiswa, artinya semakin tinggi harga diri semakin rendah prokrastinasi akademik dan berlaku sebaliknya. Penelitian dengan variabel lain juga menemukan bahwa terdapat hubungan kebalikan antara tingkat prokrastinasi dan self-efficacy. Dengan kata lain, tingkat prokrastinasi akademik bertambah jika self-efficacy menurun (Martyana, 2013).

Permasalahan prokrastinasi akademik yang dimiliki oleh siswa SMP ini tidak hanya menjadi tanggung jawab guru bidang studi maupun wali kelas saja, akan tetapi juga menjadi tanggung jawab guru BK (konselor). Bimbingan dan Konseling memiliki tanggung jawab untuk memberikan pelayanan agar siswa memperoleh kesejahteraan lahir dan batin dalam proses pendidikan yang ditempuh. BK mempunyai posisi kunci di dalam kemajuan atau kemunduran pendidikan, tidak hanya terbatas pada bimbingan yang bersifat akademik tetapi juga pribadi, sosial, dan karier. Wardati \& Jauhar (2011:53) berpendapat bahwa dengan adanya BK di sekolah maka integrasi dari seluruh potensi ini dapat dimunculkan sehingga keseluruhan aspek yang muncul bukan hanya kognitif atau akademis saja tetapi juga seluruh komponen dirinya baik itu kepribadian, hubungan sosial serta memiliki nilai-nilai yang dapat dijadikan pegangan.

Tujuan dari penulisan artikel ini ialah: (1) untuk mengetahui hubungan antara konsep diri akademik dan prokrastinasi akademik siswa SMP Negeri, (2) untuk mengetahui hubungan antara efikasi diri akademik dan prokrastinasi akademik, (3) untuk mengetahui hubungan antara harga diri dan prokrastinasi akademik, 


\section{Tabel 1. Ringkasan Hasil Uji Reliabilitas Uji Coba Instrument}

\begin{tabular}{lrrc}
\hline \multicolumn{1}{c}{ Instrument } & Cronbach's Alpha & N of Items & Keterangan \\
\hline Prokrastinasi akademik & 0.821 & 48 & Reliabel \\
Konsep diri akademik & 0.836 & 30 & Reliabel \\
Efikasi diri akademik & 0.881 & 30 & Reliabel \\
Harga diri & 0.839 & 52 & Reliabel \\
\hline
\end{tabular}

(4) untuk mengetahui hubungan keempat variabel tersebut. Manfaat praktis yang bisa didapat ialah sebagai informasi dan dapat sebagai acuan dalam pemberian layanan bimbingan, karena keempat variabel tersebut memiliki hubungan, sehingga prokrastinasi akademik pada siswa SMP dapat dikurangi atau dicegah dengan meningkatkan konsep diri akademik, efikasi diri akademik dan harga diri.

\section{METODE}

Pendekatan yang digunakan ialah kuantitatif dengan rancangan penelitian korelasional yang variabel bebas (independent) dalam penelitian ini yaitu konsep diri akademik, efikasi diri akademik dan harga diri, sedangkan variabel terikat (dependent) ialah prokrastinasi akademik. Populasi penelitian adalah seluruh siswa yang mengikuti pendidikan pada tingkat Sekolah Menengah Pertama (SMP) Negeri di kota Malang tahun ajaran 2015-2016. Teknik pengambilan sampel dalam penelitian ini menggunakan multistage random sampling (pengambilan sampel bertahap).

Tahap-tahap tersebut ialah: (1) menentukan jumlah subjek yang akan dijadikan anggota sampel, dengan menggunakan rumus Slovin, sehingga dari populasi 21.124 siswa dengan batas ketelitian 0,05, diperoleh jumlah sampel sebesar 392,56 dibulatkan menjadi 393 siswa, (2) menggunakan metode cluster sampling, metode yang digunakan untuk memilih sampel yang berupa kelompok dari beberapa kelompok (group atau cluster) dimana setiap kelompok terdiri atas beberapa unit yang lebih kecil (elements). Dari 25 SMP Negeri yang ada di kota Malang terdiri dari lima wilayah kecamatan, kemudian dari setiap kecamatan diambil satu sekolah dengan cara diundi. SMPN 13 Malang mewakili kecamatan Lowokwaru, SMPN 9 Malang mewakili kecamatan Klojen, SMPN 10 Malang mewakili kecamatan Kedungkandang, SMPN 12 Malang mewakili kecamatan Sukun dan SMPN 24 Malang mewakili kecamatan Blimbing, (3) selanjutnya menentukan kelas yang menjadi responden dengan cara acak dan berdasarkan saran dari konselor sekolah.

Pengumpulan data diperoleh menggunakan skala sebagai instrumen. Data harga diri menggunakan inventori yang diadaptasi dari Self-esteem Inventory (SEI) Coopersmith (1967) (dalam Mangantes, 2005). Data konsep diri akademik diperoleh melalui skala yang dikembangkan oleh peneliti berdasarkan pendapat Hattie (Thalib, 2010:123). Data mengenai efikasi diri akademik diadaptasi dari skala Mumpuni (2015) sedangkan data prokrastinasi akademik diadaptasi dari skala Taneo (2014). Sebelum instrumen disebarkan instrumen melalui tahap uji coba skala yaitu untuk mengetahui tingkat validitas dan reliabilitas instrumen. Uji coba diberikan kepada siswa kelas VII E dan VII I di SMPN 13 Malang, bertempat di ruangan kelas masing-masing. Penghitungan validitas dilakukan menggunakann SPSS 21 for Windows, hasil uji reliabilitas skala disajikan dalam tabel 1 .

Data penelitian yang telah terkumpul selanjutnya diolah untuk menjawab rumusan masalah dalam penelitian ini, khsusnya untuk menjawab hipotesis penelitian. Untuk teknik analisis data, digunakan analisis korelasi yang meliputi uji normalitas dan uji liniearitas serta analisis regeresi linier berganda.

\section{HASIL}

Sebelum pengujian hipotesis dilakukan, haruslah dipenuhi persyaratan analisis terlebih dahulu melalui beberapa proses uji prasyarat. Uji prasyarat yang dilakukan adalah uji normalitas, uji linieritas, uji multikolinearitas dan heteroskedastisitas. 


\section{Hasil Pengujian Persyaratan Analisis}

Hasil uji normalitas menunjukkan bahwa variabel konsep diri akademik (X1) memiliki nilai signifikansi 0,055, variabel efikasi diri akademik (X2) diperoleh nilai signifikansi 0,177, harga diri (X3) diperoleh nilai signifikansi 0,200 dan variabel prokrastinasi akademik (Y) diperoleh nilai signifikansi 0,141. Karena nilai signifikansi keempat variabel lebih besar dari 0,05, maka dapat disimpulkan bahwa seluruh data pada keempat variabel berdistribusi normal dengan keterangan nilai sig e" 0,05 .

Hasil uji linieritas menunjukkan bahwa konsep diri akademik (X1) dengan prokrastinasi akademik (Y) memiliki nilai signifikansi $0,000<0,05$, artinya variabel konsep diri akademik dengan prokrastinasi akademik berhubungan secara linieritas. Nilai signifikansi variabel efikasi diri akademik (X2) dengan prokrastinasi akademik (Y) memiliki nilai signifikansi $0,000<0,05$, artinya efikasi diri akademik dengan prokrastinasi akademik berhubungan secara linieritas. Untuk hasil uji linier variabel harga diri (X3) dengan prokrastinasi akademik memiliki nilai signifikansi $0,000<0,05$, artinya self-esteem dengan prokrastinasi akademik berhubungan secara linieritas.

Hasil uji multikolinieritas dapat ditentukan dengan patokan adanya multikolinieritas apabila menunjukkan nilai tolerance $<0,10$ atau sama dengan nilai VIF $>10$. Konsep diri akademik memiliki nilai tolerance 642 $(>0,10)$ dan nilai VIF 1,557 $(<10)$ sehingga konsep diri akademik tidak terjadi multikolinieritas. Efikasi diri akademik memiliki nilai tolerance $.657(>0,10)$ dan nilai VIF 1,523 $(<10)$ sehingga efikasi diri akademik tidak terjadi multikolinieritas. Harga diri memiliki nilai tolerance $.727(>0,10)$ dan nilai VIF 1,376 $(<10)$ sehingga harga diri tidak terjadi multikolinieritas.

Uji asumsi heteroskedastisitas dilakukan terhadap data penelitian dengan berpatokan pada pola tertentu pada grafik scatterplot analisis regresi dasar pengambilan keputusan adalah jika tidak terdapat pola yang jelas serta titik-titik menyebar di atas dan di bawah angka 0 pada sumbu Y, maka data tersebut tidak terjadi heteroskedastisitas. Pada data penelitian ini ditemukan bahwa pada grafik sebaran data tampak titik-titik menyebar di atas dan di bawah angka 0 sumbu Y, tidak terjadi pola tertentu sehingga dapat disimpulkan bahwa tidak terjadi heteroskedastisitas.

\section{Hasil Pengujian Hipotesis}

\section{Hasil Pengujian Hipotesis Hubungan antara Variabel Konsep Diri Akademik dengan Prokrastinasi Akademik}

Hasil analisis menunjukkan bahwa $t_{\text {hitung }}=|-2,973|\left(>t_{\text {tabel }} 1,966\right)$, nilai Sig $=0,003(<0,05)$, menunjukkan bahwa $\mathrm{H}_{0}$ ditolak dan $\mathrm{H}_{1}$ diterima. Artinya, konsep diri akademik (X1) memiliki hubungan negatif signifikan dengan prokrastinasi akademik (Y) siswa SMP Negeri di Kota Malang.

\section{Hasil Pengujian Hipotesis Hubungan antara Efikasi Diri Akademik dengan Prokrastinasi Akademi}

Hasil analisis menunjukkan bahwa $t_{\text {hitung }}=|-4,725|\left(>t_{\text {tabel }} 1,966\right)$, nilai Sig $=0,000(<0,05)$, menunjukkan bahwa $\mathrm{H}_{0}$ ditolak dan $\mathrm{H}_{1}$ diterima. Artinya, efikasi diri akademik (X2) memiliki hubungan negatif signifikan dengan prokrastinasi akademik (Y) siswa SMP Negeri di Kota Malang.

\section{Hasil Pengujian Hipotesis Hubungan Antara Self-Esteem dengan Prokrastinasi Akademik.}

Hasil analisis menunjukkan bahwa $t_{\text {hitung }}=|-9,401|\left(>t_{\text {tabel }} 1,966\right)$, nilai Sig $=0,000(<0,05)$, menunjukkan bahwa $\mathrm{H}_{0}$ ditolak dan $\mathrm{H}_{1}$ diterima. Artinya, self-esteem (X3) memiliki hubungan negatif signifikan dengan prokrastinasi akademik (Y) siswa SMP Negeri di Kota Malang.

Hasil Pengujian Hipotesis Hubungan Antara Konsep Diri Akademik, Efikadi Diri Akademik, Selfesteem dengan Prokrastinasi Akademik

Berdasarkan pengujian, hasil analisis regresi linear berganda menunjukkan bahwa diketahui nilai $\mathrm{F}=$ 96,288 dengan nilai signifikan sebesar 0,000 lebih kecil dari $0,05(\mathrm{p}=0,000<0,05)$ sehingga $\mathrm{H}_{0}$ ditolak. Karena $\mathrm{H}_{0}$ ditolak maka hipotesis keempat yang menyatakan bahwa ada hubungan signifikan secara simultan antara 
variabel X1, X2, X3 dengan Y dapat diterima. Dengan demikian dapat dijelaskan bahwa variabel konsep diri akademik (X1), efikasi diri akademik (X2), self-esteem (X3) secara serentak (simultan) mempunyai hubungan signifikan dengan prokrastinasi akademik (Y). Besar nilai koefisien regresi masing-masing variabel adalah sebagai berikut: variabel konsep diri akademik (X1) mempunyai nilai koefisien regresi sebesar -0,171, efikasi diri akademik (X2) mempunyai nilai koefisien regresi sebesar -0,219, self esteem (X3) mempunyai nilai koefisien regresi sebesar -0,297. Variabel self-esteem (X3) memberikan konstribusi tertinggi terhadap prokrastinasi akademik dibanding dengan variabel bebas (X) lainnya.

\section{PEMBAHASAN}

\section{Hubungan antara Konsep Diri Akademik Dengan Prokrastinasi Akademik pada Siswa SMP Negeri}

Hamachek (dalam Abdillah, 2011) menerangkan dengan konsep diri akademik yang positif akan meminimalisir munculnya kesulitan belajar dalam diri siswa. Berkurangnya kesulitan belajar inilah yang pada akhirnya memungkinkan siswa untuk mendapatkan penguasaan akademik yang lebih baik. Konsep diri akademik individu ikut berpengaruh seiring pertumbuhan fisik, kognitif dan psikososial individu tersebut. Konsep diri akademik pada individu remaja atau siswa SMP jika dikaitkan dengan prokrastinasi akademik menjadi salah satu hal yang saling mempengaruhi. Prokrastinasi akademik ialah suatu penundaan untuk memulai maupun menyelesaikan dalam konteks tugas akademik dikarenakan siswa memiliki gambaran negatif terhadap diri. Seseorang dikatakan mempunyai konsep diri negatif jika ia meyakini dan memandang bahwa dirinya lemah, tidak berdaya, tidak dapat berbuat apa-apa, tidak kompeten, gagal, malang, tidak menarik, tidak disukai dan kehilangan daya tarik terhadap hidup. Berkaitan dengan prokrastinasi akademik, individu dengan konsep diri negatif akan cenderung bersikap pesimistik terhadap kehidupan dan kesempatan yang dihadapinya. Sehingga tugas yang diterima pada akhirnya tidak segera diselesaikan melainkan mencari kesibukkan lain. Konsep diri merupakan penentu penting dari respon individu terhadap lingkungan. Bila konsep diri siswa positif, maka aktivitas belajarnya akan dipengaruhi ke arah positif. Sebaliknya jika konsep diri siswa negatif, maka perilaku belajarnya akan dipengaruhi ke arah negatif. Pendapat tersebut diperkuat oleh hasil penelitian Melina (2014) dalam penelitiannya yang berjudul "Hubungan Antara Konsep Diri Dengan Prokrastinasi Akademik Pada Mahasiswa Universitas Gunadarma" hasil pengolahan data menunjukkan terdapat hubungan sangat signifikan antara konsep diri dengan prokrastinasi akademik pada mahasiswa Universitas Gunadarma. Pemaparan-pemaparan tersebut dapat ditarik kesimpulan bahwa semakin tinggi konsep diri akademik siswa maka semakin rendah prokrastinasi akademik siswa karena dengan konsep diri akademik yang dimiliki membuat individu semakin termotivasi untuk meningkatkan keberhasilan belajar bukan mempersulit belajar.

\section{Hubungan Antara Efikasi Diri Akademik dengan Prokrastinasi Akademik pada Siswa SMP Negeri}

Efikasi diri berhubungan dengan keyakinan bahwa diri memiliki kemampuan melakukan tindakan yang diharapkan (Bandura, dalam Alwisol 2009:284). Efikasi diri menentukan seberapa besar usaha yang diberikan seseorang dalam melakukan aktifitasnya, seberapa lama mereka dapat bertahan menghadapi kesulitan dan seberapa fleksibel mereka dapat menghadapi sesuatu yang berlawanan dengan keyakinan mereka. Siswa yang memiliki efikasi diri yang tinggi akan lebih mampu menghadapi tugas akademik dengan penuh keyakinan sehingga motivasi dan level energi yang dimiliki akan lebih tinggi dari pada yang memiliki efikasi diri rendah. Sementara itu, siswa yang memiliki efikasi diri rendah cenderung kurang gigih dalam proses belajar, lebih suka menghindari tugas, dan mudah putus asa. Hal tersebut sangat terkait dengan kemungkinan terjadinya prokrastinasi akademik. Friend (dalam Timpe, 1999:341) berpendapat bahwa prokrastinasi akademik dipengaruhi oleh beberapa faktor yaitu, tidak yakin diri, toleransi frustasi rendah, menuntut kesempurnaan, perbedaan jenis kelamin, dan pandangan fatalistik. 


\section{Hubungan antara Self-esteem Dengan Prokrastinasi Akademik pada Siswa SMP Negeri}

Secara umum, self-esteem dapat diartikan sebagai menghargai diri atau harga diri. Menurut Coopersmith (dalam Mangantes, 2005) self-esteem sebagai sesuatu yang umum, mengandung pengertian bahwa selfesteem tidak dilihat faktor demi faktor atau aspek demi aspek, tetapi self-esteem dilihat secara menyeluruh, global dan sebagai satu kesatuan yang bulat. Menurut Branden (dalam Hanafiah, 2012), self esteem adalah penilaian diri yang dilakukan seseorang terhadap dirinya berdasarkan pengalaman sebelumnya. Bila penilaian tersebut rendah seperti rasa kompetensi yang rendah dan merasa tidak diterima orang lain, maka individu tergolong dalam low self-esteem. Apabila penilaiannya tinggi seperti rasa kompetensi tinggi dan merasa diterima orang lain, maka orang tersebut memiliki high self-esteem. Individu yang tergolong dalam low self-esteem memiliki penilaian negatif juga terhadap tugas yang diterima, sehingga respon yang ditunjukkan merupakan respon negatif yaitu dengan prokrastinasi akademik. Self esteem yang tingggi atau high selfesteem sangat penting bagi setiap individu, untuk membuat diri semakin tertantang dan terus berperilaku produktif dalam membuat perubahan yang lebih baik. Karena itu setiap orang perlu memahami dirinya sebagai seseorang yang berharga, mampu untuk menguasai tugas dan mampu menghadapi tantangan dalam kehidupan.

\section{Hubungan antara Konsep Diri Akademik, Efikasi Diri Akademik, Self-Esteem dengan Prokrastinasi Pada Siswa SMP}

Prokrastinasi akademik pada individu atau siswa SMP merupakan suatu fenomena yang kompleks yang berkaitan dengan komponen pikiran, perasaan, dan perilaku (Popoola, 2005). Berkaitan dengan pikiran ialah pola pikir tidak tepat atau menyimpang (irational belief) tentang kegiatan akademik dan keyakinan akan kegagalan. Siswa salah mempersepsikan tugas sekolah, memandang tugas sebagai sesuatu yang berat dan tidak menyenangkan. Selain itu berpikir bahwa tugas sekolah merupakan tugas yang sulit dan membutuhkan usaha keras dan waktu yang lama. Irrational perfectionism (kesempurnaan yang irasional), ialah pribadi yang menginginkan kesempurnaan yang tidak masuk akal saat menyelesaikan kegiatan akademik dan berusaha untuk melakukan hal yang mustahil atau tidak mungkin dicapai. Pemikiran seperti ini, cenderung membuat siswa melakukan prokrastinasi akademik. Kemampuan variabel konsep diri akademik (X1), efikasi diri akademik (X2), self-esteem (X3) secara simultan memberikan kontribusi terhadap perubahan prokrastinasi akademik sebesar $42 \%$, sedangkan sisanya sebesar 58\% dipengaruhi oleh variabel lain diluar variabel X1, $\mathrm{X} 2$, dan X3. Dari ketiga variabel tersebut yang paling besar mempengaruhi prokrastinasi ialah harga diri (self-esteem). Self-esteem (harga diri) merupakan salah satu aspek dari kepribadian dan merupakan suatu landasan yang mampu memberikan keyakinan terhadap diri dan lingkungan sekitar. Harga diri didefinisikan rasa menyukai dan menghargai diri sendiri dengan berdasarkan pada hal-hal yang praktis, perasaan ini biasanya mempengaruhi proses berfikir, perasaan, keinginan, nilai, maupun tujuan hidupnya yang diperoleh dari interaksi dengan lingkungan terdekatnya dan dari sejumlah penghargaan, penerimaan, dan perlakuan orang lain. Menurut Worchel, dkk (dalam Dayakisni, 2009) self-esteem merupakan komponen evaluatif dari konsep diri, yang terdiri dari evaluasi positif dan negatif tentang diri sendiri. Berdasarkan pernyataan tersebut, dapat disimpulkan bahwa self-esteem memiliki peran penilaian secara keseluruhan terhadap kepribadian individu yaitu menilai diri menjadi positif atau negatif tentang konsep diri dan efikasi diri yang telah dimiliki individu itu sendiri. Jika konsep diri dan efikasi diri yang dimiliki oleh individu tersebut mampu dinilai menjadi positif, maka individu berada pada high self-esteem. Sedangkan individu yang tidak mampu menilai secara positif konsep diri dan efikasi dirinya, maka individu berada pada low self-esteem. Sangat diperlukan bagi individu memiliki self-esteem yang baik, karena perilaku yang nampak mencerminkan self-esteem individu.

\section{Implikasi Temuan Penelitian dalam Layanan Bimbingan dan Konseling di Sekolah}

Setiap individu memiliki respon yang berbeda ketika mengikuti proses belajar, beberapa individu yang mampu menyesuaikan diri dapat melaksanakan seluruh kegiatan belajar tanpa ada masalah. Beberapa masalah individu dalam proses belajar sering dikarenakan oleh pengaturan waktu belajar, pemilihan cara belajar, 
ketidak cocokan dengan mata pelajaran, kesulitan konsentrasi, mudah lupa, penundaan dalam mempersiapkan ujian dan lain sebagainya. Bimbingan dan konseling (BK) mempunyai posisi kunci di dalam kemajuan atau kemunduran pendidikan, tidak hanya terbatas pada bimbingan yang bersifat akademik tetapi juga pribadi, sosial, dan karier. Wardati \& Jauhar (2011:53) menyebutkan bahwa dengan adanya BK di sekolah maka integrasi dari seluruh potensi ini dapat dimunculkan sehingga keseluruhan aspek yang muncul bukan hanya kognitif atau akademis saja tetapi juga seluruh komponen dirinya baik itu kepribadian, hubungan sosial serta memiliki nilai-nilai yang dapat dijadikan pegangan. Peran BK di dalam meningkatkan mutu pendidikan terletak pada bagaimana BK membangun manusia yang seutuhnya dari berbagai aspek yang ada di dalam diri siswa. Kesulitan belajar individu dapat dilihat dari gejala seperti rendahnya hasil belajar, hasil yang dicapai tidak seimbang dengan usaha yang dilakukan, membolos, menghindari pertemuan mata pelajaran, dan terlambat mengumpulkan tugas yang mengarah pada kebiasaan menunda (prokrastinasi akademik). Hasil penelitian hubungan antara konsep diri akademik, efikasi diri akademik, harga diri dan prokrastinasi akademik dapat diimplementasikan dalam kegiatan BK di sekolah. Melalui perencanaan program BK, konselor dapat memberikan tambahan layanan informasi khususnya dalam bidang bimbingan belajar kepada siswa. Layanan informasi bidang bimbingan belajar dapat diberikan konselor melalui bimbingan kelompok maupun bimbingan klasikal (kelas).

\section{SIMPULAN DAN SARAN}

\section{Simpulan}

Berdasarkan hasil penelitian dapat ditarik simpulan bahwa: (1) terdapat hubungan negatif antara konsep diri akademik dengan prokrastinasi akademik pada siswa SMP Negeri di Kota Malang. Artinya, semakin tinggi tingkat konsep diri akademik siswa maka semakin rendah prokrastinasi akademik siswa, begitu sebaliknya, (2) terdapat hubungan negatif antara efikasi diri akademik dengan prokrastinasi akademik pada siswa SMP Negeri di Kota Malang. Artinya, semakin tinggi tingkat efikasi diri akademik siswa maka semakin rendah prokrastinasi akademik siswa, begitu sebaliknya, (3) terdapat hubungan negatif antara self-esteem dengan prokrastinasi akademik pada siswa SMP Negeri di Kota Malang. Artinya, semakin tinggi tingkat selfesteem siswa maka semakin rendah prokrastinasi akademik siswa, begitu sebaliknya, (4) konsep diri akademik, efikasi diri akademik, self-esteem secara serentak (simultan) berpengaruh negatif terhadap perubahan prokrastinasi akademik, dari data analisis diantara ketiga variabel tersebut yang paling besar mempengaruhi prokrastinasi akademik ialah self-esteem.

\section{Saran}

Ada beberapa saran yang disampaikan terkait penelitian ini. Pertama bagi Guru BK (konselor), dapat membantu siswa dalam meningkatkan konsep diri akademik, efikasi diri akademik dan self-esteem agar dapat menghindari diri dari perilaku menunda (prokrastinasi akademik). Kedua ditujukan bagi peneliti selanjutnya, hendaknya dapat meneliti kembali mengenai hubungan konsep diri akademik dengan prokrastinasi akademik, karena hasil yang didapat dari penelitian ini masih jauh pengaruhnya dibandingkan efikasi diri akademik dan self-esteem atau dapat melanjutkan penelitian dengan Penelitian Pengembangan sehingga menghasilkan sebuah product berupa buku panduan pelatihan untuk mengurangi prokrastinasi akademik siswa SMP.

\section{DAFTAR RUJUKAN}

Abdillah, R. 2011. Perbedaan Konsep Diri Akademik Antara Siswa Internasional Budi Mulia Dua Yogyakarta Dan SMK Diponegoro Yogyakarta, Skripsi (tidak diterbitkan). Fakultas ilmu Sosial \& Humaniora. Program Studi Psikologi. Universitas Islam Negeri Sunan Kalijaga Yogyakarta, (Online), (http://digilib.uin-suka.ac.id/6060/1/BAB\%20I,V,\%20DAFTAR\%20PUSTAKA.pdf, diakses 23 November 2015). 
Alvira, M. 2013. Keefektifan Teknik Self Management Untuk Mereduksi Prokrastinasi Akademik Siswa SMP. Skripsi tidak diterbitkan. Malang: Jurusan Bimbingan dan Konseling Fakultas Ilmu Pendidikan Universitas Negeri Malang.

Alwisol. 2009. Psikologi Kepribadian. Malang: UMM Press.

Atmasari. 2009. Studi Deskriptif Mengenai Konsep Diri Akademik dan Perencanaan Karier Pada Remaja yang Memiliki Orang Tua Sebagai Tenaga Kerja Indonesia, Skripsi tidak diterbitkan, Fakultas Psikologi Universitas Airlangga, (Online), (http//alumni.unair.ac.id/kumpulanfile/743829930.abs.pdf., diakses 30 Agustus 2015).

Dayakisni, T, \& Hudaniah. 2009. Psikologi Sosial Edisi Revisi. Malang: UMM Press.

Erma, 2013. Hubungan Antara Harga Diri Dengan Prokrastinasi Akademik Pada Mahasiswa. Fakultas Psikologi Universitas Muhammadiyah Surakarta. Skripsi. (Online) (http://eprints.ums.ac.id/ 24795/9/02._Naskah_Publikasi.pdf, diakses 22 Agustus 2015).

Ghufron, M. N. 2003. Hubungan Kontrol Diri dan Persepsi Remaja terhadap Penerapan Disiplin Orang Tua terhadap Prokrastinasi Akademik Pada Siswa Madrasah Aliyah Kota Jogjakarta. Thesis (tidak diterbitkan). Yogjakarta: Fakultas Psikologi Universitas Gadjah Mada.

Hanafiah, N.A. 2012. Hubungan Antara Self Esteem, Self Confidence, dan Self Acceptance dengan Self Disclosure Pada Remaja. Skripsi tidak diterbitkan. Malang: Fakultas Pendidikan Psikologi Jurusan Psikologi Universitas Negeri Malang.

Lampert, J. 2007. The Relationship of Self-Efficacy and Self-Concept To Academic Performance In A College Sample: Testing Competing Models and Measures. School of Professional Psychology Pacific University, (Online), (http://commons.pacificu.edu/cgi/viewcontent.cgi?article=1140\&context=spp diakses 24 November 2015).

Martyana, L. 2013. Hubungan Efikasi Diri dengan Prokrastinasi Akademik pada siswa SMA Islam Diponegoro Wagir Malang. Skripsi tidak diterbitkan. Malang: Program Studi Psikologi Universitas Negeri Malang.

Mangantes, L.M. 2005. Hubungan Antara Pola Asuh Orang Tua, Kelas Sosial, Kemampuan Umum, dan Self-Esteem Siswa SMA Negeri di Kota Malang. Tesis tidak diterbitkan. Malang: Pascasarjana Program Studi Bimbingan dan Konseling Universitas Negeri Malang.

Melina, M.R. 2014. Hubungan Antara Konsep Diri Dengan Prokrastinasi Akademik Pada Mahasiswa Universitas Gunadarma. Skripsi tidak diterbitkan. Fakultas Psikologi Universitas Gunadarma. (Online) (http://library.gunadarma.ac.id/repository/view/3782189/hubungan-antara-konsep-diri-denganprokrastinasi-akademik-pada-mahasiswa-universitas-gunadarma.html, diakses 23 September 2015).

Mumpuni, R.E. 2015. Keefektifan Symbolic Modeling Untuk Meningkatkan Efikasi Diri Akademik Siswa SMP. Tesis tidak diterbitkan. Malang: Pascasarjana Program Studi Bimbingan dan Konseling Universitas Negeri Malang.

Popoola, B. 2005. A study of the relationship between procrastinatory behaviour and academic performance of undergraduate students in a Nigerian University. African Symposium: An Online Journal of Educational Research Network, (Online), Vol. 5, No. 1, (https://www.ncsu.edu/aern/TAS5.1/ TAS5.1.pdf).

Taneo, Joris. 2014. Keefektifan Konseling Kelompok Cognitive Behavior Untuk Mereduksi Pola Pikir Prokrastinasi Akademik Siswa SMA. Tesis tidak diterbitkan. Malang: Pascasarjana Program Studi Bimbingan dan Konseling Universitas Negeri Malang.

Thalib, S.B. 2010. Psikologi Pendidikan Berbasis Analisis Empiris Aplikatif. Jakarta: Kencana Prenada Media Group.

Timpe, A.D. 1999. Seri Manajemen Sumber Daya Manusia, Mengelola Waktu. Terjemahan oleh Susanto Boedidharmo. Jakarta: PT Elex Media Komputindo, Kelompok Gramedia.

Wardati \& Jauhar, M. 2011. Implementasi Bimbingan dan Konseling di Sekolah. Jakarta: Prestasi Pustakaraya. 